ISSN 2597- 6052

DOI: https://doi.org/10.31934/mppki.v2i3

Media Publikasi Promosi Kesehatan Indonesia The Indonesian Journal of Health Promotion

Artikel Review

Open Access

\title{
Terapi Non Farmakologi dalam Pengendalian Tekanan Darah Pada Pasien Hipertensi: Systematic Review
}

\author{
Non Pharmacological Therapy in Blood Pressure Control in Hypertensive Patients: \\ Systematic Review \\ Ainurrafiq $^{\mathbf{1}}, \mathbf{R i s n a h}^{* \mathbf{2}}$, Maria Ulfa Azhar
1,2,3 Universitas Islam Negeri Aluddin Makassar
${ }^{*}$ Korespondensi Penulis : risnah_ina@yahoo.com
}

\begin{abstract}
Abstrak
Diketahuinya penerapan terapi non farmakologik pengendalian tekanan darah pada pasien hipertensi dari berbagai perbandingan. Sumber perncarian jurnal pada penelitian ini adalah Google Schoolar, DOAJ dan Portal Garuda artikel yang diterbitkan dari tahun 2015-2018, jurnal intervensi untuk mengatasi tekanan darah pada pasien hipertensi, merupakan intervensi non farmakologi, merupakan intervensi yang efisien berdasarkan hasil penelitian dan intervensi yang mudah dilakukan. Berdasarkan pada sepuluh artikel sesuai dengan kriteria inklusi. Berdasarkan sepuluh artikel tentang terapi non farmakologik dalam pengendalian tekanan darah pada pasien hipertensi membuktikan bahwa 100\% terapi non farmakologik efektif dalam menurunkan tekanan darah pada pasien hipertensi. Teknik non farmakologik yang digunakan dalam jurnal yang terpilih yaitu, pemberian juice campuran tomat dan mentimun, pemberian juice belimbing dan buah naga, pemberian jus papaya mengkal dalam, pemberian madu, relaksasi menggenggam jari dan nafas dalam, terapi bekam, pemberian air rebusan daun salam, pemberian terapi music suara alam, terapi Healing Touch, dan terapi Slow Deep Breating Berdasarkan 10 jurnal yang terpilih sesuai dengan kriteria inklusi, terapi non farmakologik yang efektif dalam mengendalikan tekanan darah pada pasien hipertensi adalah pemberian juice campuran tomat dan mentimun, pemberian madu, terapi relaksasi genggam jari dan nafas dalam, terapi music suara alam dan slow deep breating
\end{abstract}

Kata Kunci : Terapi non Farmakologik, Hipertensi. Systematic review

\begin{abstract}
Knowing the application of non-pharmacologic therapy in controlling blood pressure in hypertensive patients from various comparisons. Journal search sources in this study are Google Schoolar, DOAJ and Garuda Portal articles published from 2015-2018, intervention journals to treat blood pressure in hypertensive patients, non-pharmacological interventions, are efficient interventions based on research results and easy interventions. Based on ten articles according to inclusion criteria. Based on ten articles on non-pharmacological therapy in controlling blood pressure in hypertensive patients, it is proven that $100 \%$ of non-pharmacologic therapy is impressive in reducing blood pressure in hypertensive patients. Non-pharmacological techniques used in selected journals are, giving a mixture of tomato and cucumber juice, giving star fruit juice and dragon fruit, giving papaya juice in, giving honey, relaxing grasping fingers and breathing in, cupping therapy, giving bay leaf boiled water, provision of natural sound music therapy, Healing Touch therapy, and Slow Deep Breating therapy based on 10 selected journals according to inclusion criteria, effective non-pharmacological therapy in controlling blood pressure in hypertensive patients is giving a mixture of tomato and cucumber juice, honey administration, relaxation therapy finger grip and deep breathing, natural sound music therapy and slow great breathing
\end{abstract}

Keywords : Non Pharmacologic Therapy, Hypertension. Systematic review 


\section{PENDAHULUAN}

Hipertensi berawal dari bahasa latin yaitu hiper dan tension. Hiper ialah tekanan yang berlebihan dan tension ialah tensi. Hipertensi merupakan kondisi dimana terjadi peningkatan tekanan darah secara kronis (dalam kurun waktu yang lama) yang dapat menyebabkan kesakitan pada seseorang dan bahkan dapat menyebabkan kematia. Seseorang dapat disebut menderita hipertensi jika didapatkan tekanan darah sistolik >140 $\mathrm{mmHg}$ dan diastolik $>90 \mathrm{mmHg}$ (Yeyeh, 2010). Tekanan darah yang selalu tinggi dan tidak diobati atau dicegah sejak dini, maka sangat berisiko menyebabkan penyakit degeneratif seperti retinopati, penebalan dinding jantung, kerusakan ginjal, jantung koroner, pecahnya pembuluh darah, stroke, bahkan dapat menyebabkan kematian mendadak (1).

Hipertensi ialah suatu masalah kesehatan yang cukup tinggi di dunia. Menurut data World Healty Organization (WHO) (2015) menunjukan prevelensi penderita hipertensi terjadi pada kelompok umur dewasa yang berumur $\geq 25$ tahun yaitu sekitar $40 \%$. Hipertensi diprediksi dapat menyebabkan kematian yaitu sekitar 7,5 juta dan penyebab kematian di dunia yaitu sekitar 12,8\%. Adapun di Amerika Serikat diprediksi terdapat $33,8 \%$ penduduknya menderita hipertensi yang terjadi pada jenis kelamin laki-laki maupun perempun. Adapun di Indonesia, prevelensi penderita hipertensi menurut Depertemen Kesehatan yaitu terdapat sekitar $31,7 \%$, dimana hanya 7,2 dari $31,7 \%$ penduduk yang mempunyai pemahaman mengenai hipertensi serta terdapat kejadian yang minum obat hipertensi hanya sekitar $0,4 \%$ (2).

Penderita hipertensi yang tidak rutin mengontrol tekanan darahnya akan muncul komplikasi penyakit yang sangat beresiko bagi kesehatannya jika hanya didiamkan tanpa adanya perawatan yang tepat, adapun komplikasi yang dapat ditimbulkan dari hipertensi yaitu penyakit jantung koroner (PJK) dan stroke yang sangat membutuhkan perawatan yang lebih serius lagi. Kedua penyakit tersebut merupakan masalah yang paling tinggi di seluruh dunia. WHO meprediksi bahwa PJK dapat menyebabkan 7,3 juta kematian setiap tahunnya serta stroke juga penyebab kematian di dunia yaitu sekitar 6,2 juta kasus. Sehingga penderita hipertensi sangat perlu melakukan kontrol tekanan darah supaya tidak terjadi komplikasi yang lebih berbahaya dari hipertensi tersebut. Sebagian besar seseorang baru dapat menyadari ketika muncul komplikasi dari hipertensi seperti jantung coroner, stroke, gagal ginjal dan penyakit lainnya yang lebih urgen dari hipertensi (3).

Riskesdas (2018), menjelaskan Hipertensi merupakan penyakit tidak menular yang memiliki prevalensi tertinggi yang didiagnosa di fasilitas kesehatan dengan jumlah kasus mencapai 185.857. Prevalensi hipertensi di Indonesia pada umur $\geq 18$ tahun sebesar $34,1 \%$ dengan penderita hipertensi tertinggi di Kalimantan selatan sebesar 44,1\% sedangkan untuk Sulawesi selatan menempati urutan ke 13 tertinggi dengan 31,9\%. Berdasarkan jenis kelamin Prevalensi hipertensi pada perempuan cenderung lebih tinggi daripada laki-laki dengan dan prevalensi hipertensi di perkotaan cenderung lebih tinggi daripada di pedesaan.Prevalensi hipertensi di Indonesia pada kelompok usia 15-24 tahun adalah $13,2 \%$ pada kelompok usia 25-34 tahun adalah 20,1\%, kelompok umur 35-44 tahun 31,6\% usia 45-54 tahun 45,3\%, usia55-64 tahun 55,2\% untuk usia 65-74 tahun $63,2 \%$ sedangkan lebih dari 75 tahun adalah $69,5 \%$, dengan prevalensi yang tinggi tersebut hipertensi yang tidak disadari jumlahnya bisa lebih tinggi lagi (4). Berdasarkan data dari Bidang Bina P2PL Dinas Kesehatan Kota Makassar (2015) menjelasakan terdapat kasus hipertensi sebanyak 11,596 dengan rincian jenis kelamin laki - laki 4.277 kasus dan perempuan 7319 kasus (5)

Hipertensi tidak pandang bulu siapa saja dapat mengalaminya, penyakit ini umumnya dialami oleh orang dewasa, namun oleh sebab tertentu anak-anak juga dapat mengalami hipertensi misalnya karena kondisi bawaan terkait dengan ketidakmampuan tubuhnya menghasilkan nitrogen monoksida atau karena mengalami kelainan ginjal. Secara alamiah, tekanan darah anak-anak lebih rendah daripada tekanan darah orang dewasa. Tekanan darah tersebut akan meningkatkan sejalan dengan pertambahan usia. Anak usia 8- 12 tahun setiap tahun mengalami peningkatan tekanan darah sistolik yaitu $0,44 \mathrm{mmHg}$ serta tekanan darah diastolik yaitu 2,90 $\mathrm{mmHg}$. Sementara itu remaja berusia 13-17 tahun mengalami peningkatan tekanan darah sistolik sebesar $0,33 \mathrm{mmHg}$ per tahun dan tekanan darah diastolic sebesar $1,81 \mathrm{mmHg}$ per tahun. Tidak hanya orang dewasa para remaja juga berpotensi mengalami tekanan darah tinggi (6).

Hipertensi dapat disertai gejala ataupun tanpa gejala yang memberi ancaman terhadap kesehatan secara terus-menerus (Vitahealth, 2005 dalam Situmorang, 2015). Gejala yang sering muncul berupa nyeri kepada kepala atau rasa berat pada tengkuk, vertigo, merasa selalu berdebar-debar, merasa mudah lelah, penglihatan kabur, telinga berdenging, serta dapat mengalami mimisan. Jika terjadi peningkatan tekanan darah dalam kurun waktu lama dapat menyebabkan rusaknya jaringan pada ginjal atau biasa disebut gagal ginjal, juga dapat terjadi jantung koroner serta gangguan pada otak yang dapat menimbulkan penyakit stroke, sehingga sangat penting untuk mendeteksi lebih awal tekanan darah agar lebih mudah mendapatkan pengobatan (7).

Menghadapi pasien hipertensi diperlukan adanya kepatuhan perawatan diri mereka untuk meningkatkan derajat kesehatan. Perawatan diri 
hipertensi meliputi diet rendah garam, mengurangi konsumsi alkohol, tidak merokok, olahraga atau latihan fisik, dan konsumsi obat hipertensi. Salah satu komponen yang mempengaruhi perawatan diri pasien hipertensi yaitu self efficacy. Penderita hipertensi yang memiliki self efficacy baik dapat menghasilkan manfaat dalam penanganan hipertensi contohnya kepatuhan dalam mengkonsumsi obat anti hipertensi (8).

Selama ini, untuk mengatasi hipertensi dapat dilakukan berbagai upaya yaitu dapat dilakukan pengendalian tekanan darah dengan cara pemberian terapi non farmakologis berupa: modifikasi gaya hidup, mengurangi berat badan, pembatasan asupan natrium, modifikasi diet rendah lemak, pembatasan alkohol, pembatasan kafein, teknik relaksasi, dan menghentikan kebiasaan merokok (9). Terapi farmakologi berupa pemberian obat dengan Jenis-jenis medikasi antihipertensi meliputi diuretik, penyekat betaadregenik atau beta-blocker, vasodilator, penyekat saluran kalsium dan penghambat enzim pengubah angiotensin (ACE) (10).

Mengonsumsi obat antihipertensi dalam jangka yang lama dapat menyebabkan terjadinya Drug Related Problems. Drug Related Problems adalah merupakan suatu keadaan yang tidak diharapkan yang dialami pasien yang terlibat, dimana kemungkinan disebabkan dalam melibatkan terapi pengobatan yang diberikan kepada pasien, yang secara nyata maupun potensial dapat mempengaruhi keadaan pasien seperti ketidak-patuhan, interaksi obat, alergi terhadap obat yang diresepkan. Adapun, pengobatan dalam jangka yang lama dapat menimbulkan efek samping obat yang menyebabkan terjadinya kerusakan pada beberapa organ tertentu (11).

Melihat kejadian di atas, menandakan bahwa terapi obat adalah bukan hanya pilihan alternatif terapi dapat digunakan. Diperlukan alternatif terapi lain yang bertujuan mengurangi tingkat ketergantungan pada obat untuk dapat mempertahankan kualitas hidup pasien hipertensi. Berdasarkan penelitian eksperimen yang dilakukan oleh yuni afrianty mantong (2017) di kabupaten toraja utara. Ditemukan bahwa terdapat perbedaan yang signifikan antara rata-rata tekanan darah responden pada kelompok control dan kelompok perlakuan dengan diberikan . Sehingga dapat disimpulkan bahwa ada pengaruh pemberian air rebusan daun alpukat (Persea americana Mill) terhadap penurunan tekanan darah pasien hipertensi. Daun buah alpukat mempunyai kegunaan sangat beragam untuk mengatasi berbagai masalah kesehatan selain itu Kadar kalium yang sangat tinggi dalam $100 \mathrm{mg}$ ekstrak daun alpukat yaitu sebanyak 148,92 mg dapat menyebabkan dilastasi pembuluh darah sehingga menimbulkan efek antihipertensi.
Hasil penelitian tentang efektifitas isometric handgrip exercise dan slow deep breathing exercise terhadap perubahan tekanan darah pada pasien hipertensi, hasil penelitian tersebut menunjukkan bahwa terdapat perubahan tekanan darah sistolik dan diastolik setelah diberikan intervensi Isometric Handgrip Exercise $(t=8,279, \quad p=0,000), \quad(t=6,154$, $\mathrm{p}=0,000$ ), demikian pula setelah diberikan intervensi Slow Deep Breathing Exercise terjadi perubahan tekanan darah sistolik maupun diastolik yaitu dengan nilai $(t=3,632, p=0,002),(t=4,226, p=0,001)$. Sehingga dapat disimpulkan bahwa intervensi isometric handgrip exercise dan slow deep breathing exercise dapat menurunkan tekanan darah sistolik dan diastolik secara signifikan padapenderita hipertensi (12).

Terapi non farmakologi mempunyai efek relaksasi untuk tubuh dan mampu menurunkan kadar natrium dalam darah sehinga mampu mengendalikan tekanan darah. Berdasarkan uraian diatas penulis tertarik untuk menganalisi terkait teknik non farmakologi untuk mengendalian tekanan darah pada penderita hipertensi dari berbagai literature yang telah terpublikasi.

\section{METODE}

Sumber jurnal pada penelitian ini adalah menggunakan database google schoolar, Directory Of Open Access Journal (DOAJ), portal garuda dengan artikel tahun 2015-2018, Fulltext Artikel yang sesuai dengan topik, terdapat ISSN atau DOIJurnal Intervensi untuk menurunan tekanan darah pada pasien Hipertensi merupakan intervensi non farmakologi, intervensi yang efisien berdasarkan hasil penelitian dan intervensi yang mudah dilakukan. Setelah menggumpulkan data dan informasi, semua data diseleksi sesuai dengan kriteria inklusi dan ekslusi kemudian diseleksi kerelevanan menggunakan Duffy's Research Appraisal Checklist Approach, dilanjutkan dengan analisis kompratif untuk melihat perbandingan antara pikiran utama karya tulis ini dengan beberapa teori yang relevan, dan untuk selanjutnya memberikan rekomendasi teknik non farmakologi yang dapat digunakan untuk mengendalikan tekanan darah pada pasien hipertensi.

\section{HASIL DAN PEMBAHASAN}

Berdasarkan hasil dari penelusuran jurnal penelitian didapatkan sebanyak 294 jurnal yang diidentifikasi dari ke tiga data literatur pencarian setelah dilakukan seleksi (tahun 2015-2019, penelitian yang berhubungan dengan pertanyaan penelitian). Penulis menilai semua artikel yang diidentifikasi secara independen untuk dimasukkan dalam tinjauan sistematik. Dari 294 artikel yang berpotensi tersebut, ada 37 artikel dieksklusi, karena double publikasi, 54 dieksklusi karena tidak full text, 190 dieksklusi karena tidak sesuai tujuan penelitin Studi yang diinklusi untuk 
tinjauan literatur ini Jurnal Terindeks Fulltext Artikel yang sesuai dengan topik, terdapat ISSN atau DOI, Jurnal Intervensi untuk menurunan tekanan darah pada pasien Hipertensi, merupakan Intervensi Terapi Non Farmakologis kemudian artikel dieksklusikan berdasarkan penilaian dengan Duffy's Research Appraisal Checklist Approach. Sehingga, hanya 10 artikel yang memenuhi kriteria inklusi dengan artikel intervensi.

Berdasarkan lembar penilaian Duffy's Research Appraisal Checklist Approach terdapat 3 kategori penilaian yaitu Below Average Paper (0-120), Average Paper (103-204), Superior Paper (205-306). Hasil yang didapatkan yaitu 0 jurnal dengan kategori Below Average Paper (0-120), 3 jurnal dengan kategori Average Paper (103-204) dan 10 jurnal yang termasuk kategori Supporior Paper (Skor 205-306). Artikel yang diinklusi dilakukan kirtisi dengan menggunakan instrumen penilaian dengan Duffy's Research Appraisal Checklist Approach.

Salah satu pengobatan alternatif yang dapat menjadi pilihan untuk menurunkan tekanan darah adalah terapi herbal. Terapi herbal adalah terapi komplementer menggunakan tumbuhan yang berkhasiat obat. Indonesia dikenal memiliki tumbuhan obat yang sangat banyak. Tumbuhan-tumbuhan tersebut sudah banyak dipakai masyarakat dalam pengobatan hipertensi. Khasiat antihipertensi yang dimiliki herbal tersebut diantaranya adalah kalium, memiliki kandungan antioksidan, memiliki kandungan diuretik, antiandrenergik dan vasodilator. Pada penelitian ini ada beberapa jurnal, yang dijadikan intervensi terapi herbal pada pemberian terapi non farmakologi antara lain yaitu :

Tomat nama latinnya adalah Gycopersicum esculentum Mill, dan Mentimun nama latinnya adalah Cucumis Sativus L. pada tomat dan mentimun terdapat kandungan kalium sebagai antidiuretik sehingga dapat mengurangi kadar natrium ke dalam urine oleh ginjal. Pengurangan cairan dalam sirkulasi akan menurunkan tahanan perifer, sehingga dengan sendirinya tekanan darah akan menurun. Kalium tinggi akan meningkatkan konsentrasinya di dalam cairan intraseluler, sehingga cenderung menarik cairan dari bagian ekstraseluler dan menurunkan tekanan darah. Selain itu kalium dapat menimbulkan efek vasodilatasi sehingga menyebabkan penurunan retensi perifer total dan meningkatkan output jantung (13).

Dari penelitian ini penulis dapat menyimpulkan bahwa jus campuran tomat dan mentimun dapat digunakan untuk menurunkan tekanan darah pada pasien hipertensi, sehingga penderita hipertensi tidak membutuhkan biaya yang cukup besar untuk memantau tekanan darah agar tidak terjadi komplikasi- komplikasi yang sangat berbahaya bagi pasien hipertensi.

Pada umumnya buah belimbing mengandung kadar kalium yang tinggi dan rendah natrium sebagai obat anti hipertensi. 1 buah belimbing mengandung kalium (potassium) sebesar $207 \mathrm{mg}$. kondisi tersebut menunjukkan bahwa kalium dalam buah belimbing memiliki jumlah yang banyak dari jumlah mineral di dalam buah belimbing (14)

Kandungan dari buah belimbing yang memiliki kandungan kalium yang cukup tinggi dapat menurunkan tekanan darah. Dimana proses terjadinya hipertensi karena terbentuknya Angiostensin I yang diubah menjadi Angiostensin II oleh ACE (Angiostensin I - Converting Enzyme) yang dapat menaikkan tekanan darah melalui 2 aksi utama, berupa menurunkan cairan intraseluler dan meningkatkan cairan ekstraseluler pada tubuh. Akan tetapi dengan pemberian terapi buah belimbing yang tinggi akan kalium serta rendah natrium kepada penderita hipertensi, maka 2 aksi utama tersebut akan mengalami peralihan arah dari semula. Hal tersebut dapat terjadi karena jumlah kalium banyak dapat memicu penurunan produksi atau sekresi hormon antidiuretik (ADH). Dimana hormon tersebut berfungsi mengatur osmolalitas serta volume urine, dengan menurunnya ADH pada ginjal, sehingga urine yang dihasilkan oleh ginjal dapat meningkat dan kemudian dikeluarkan keluar tubuh, dengan komposisi urine yang encer dengan osmolalitas yang rendah, untuk memekatkannya volume cairan intraseluler akan ditingkatkan dengan cara menarik cairan dari bagian ekstraseluler. Sedangkan menurunnya konsentrasi $\mathrm{NaCl}$ akan dipekatkan dengan cara menurunkan cairan ekstraseluler yang kemudian akan menurunkan tekanan darah (15).

Hal ini sejalan dengan teori yang mengatakan bahwa buah belimbing dan buah naga dapat berkhasiat dalam menurunkan tekanan darah tinggi. Sehingga didapatkan hasil bahwa terjadi penurunan rata-rata sistolik dan distolik pada responden yang telah dilakukan terapi buah belimbing dan buah naga.

Pemberian buah papaya mengkal dalam buah pepaya yang masih muda mengandung banyak zat-zat kimia yang dapat bermanfaat bagi tubuh, dan paling bermafaat bagi pembuluh darah. Dimana buah papaya muda ini mengandung banyak vitamin A ( $\beta$ Karotena), vitamin $C$, Peptin, enzim papain serta kalium. Vitamin A ( $\beta$ Kartena) dan vitamin $C$ berfungsi sebagai antioksidan yang sangat bagus dalam mencegah serta memperbaiki kerusakan pembuluh darah akibat dari aktivitas molekul radikal bebas. Adapun peran peptin dapat memicu turunnya kadar kolestrol dalam darah sehingga dapat meminimalisir terjadinya penebalan pada pembuluh darah (16). 
Adapun enzim papain berperan aktif dalam memecah protein sehingga dapat terbentuk beberapa senyawa asam amino yang bersifat autointoxicating yang dapat mengurangi terbentuknya subtansi yang tidak diharapkan akibat dari pencernaan yang tidak komplit serta yang tidak berguna bagi tubuh, seperti adanya penumpukan lemak yang melewati batas di dalam tubuh yang kemudian dikeluarkan melalui feses. Enzim papain yang terdapat di pembuluh darah akan merusak partikel-partikel yang tertempel di saluran pembuluh darah yang menjadi penyebab terjadinya arterosklerosis sehingga tekanan darah bisa dikontrol (16).

Adapun jika seseorang mengonsumsi buah papaya muda secara rutin, yang diketahui mengandung banyak kalium dapat meninggkatkan konsentrasi kalium di dalam jaringan intaseluler yang kemudian memicu turunnya kadar natrium di dalam interaseluler sehingga dapat menurunkan tekanan darah. Kalium tersebut dapat menurunkan tekanan darah sistolik dan diastolik dengan kisaran 20-30 mmHg (16).

Menurut asumsi peneliti, pemberian jus pepaya muda terhadap penderita tekanan darah tinggi harus diberengi dengan pola makanan yang tepat dan pola hidup teratur, karena tanpa pola makan yang tepat dan pola hidup yang tidak teratur akan menurunkan tingkat efektifitas jus papaya muda dalam mengontrol tekanan darah yang dialami oeh penderita hipertensi.

Madu mempunyai manfaat yang baik dalam fungsi beredaran darah dalam tubuh. Selain itu madu mempunyaii berperan dalam pelindung pada pembulu darah kapiler dan arterosklerosis. Madu mempunyai kandungan $0,30,5 \mathrm{mg} / \mathrm{kg}$ kolin dan 0,06-5 mg/kg asetil kolin. Asetil kolin berperan langsung terhadap pembuluh darah dengan cara memvasodilatasi pembuluh darah selain itu asetil kolin mampu menurunankan aktivitas jantung sehingga dengan itu tekanan darah dapat mengalami penurunan (Suranto, 2008). Madu mengandung antioksidan yang dapat meningkatkan biovaiblitas nitrit oksida pada tubuh sehingga memicu terjadinya penurunan pada tekanan darah. Sel endothelial mensitesis beberapa subtansi bioaktif kuat yang mengatur struktur fungsi pembuluh darah. Subtansi ini termasuk nitrit oksida, prostaglandin, endothelin, dan angiotensin II. Madu mempunyai komposisi oksida nitrit (NO) metabolit yang mempunyai perananan dalam menurukan resiko penyakit kardiovaskuler. Dengan adanya peningkatan pada kadar nitrit oksida pada madu mempunyai fungsi sebagai pelindung pada penyakit kardiovaskuler (17).

Komposisi antioksidan yang terdapat pada madu mampu untuk memperbaiki tekanan oksidatif dan menekan serta mengurangi peningkatan tekanan darah.

Berdasarkan uraian diatas peneliti menyimpulkan bahwa madu merupakan terapi diet yang baik untuk penderita hipertensi karena kandungan antioksidan dan nitrogen oksidanya. Antioksidan dapat perbaiki tekanan oksidatif dan mengurangi peningkatan tekanan darah tetapi juga harus diimbangi dengan natrium yang cukup.

Salam (Syzgiyum polyanthum) adalah nama pohon penghasil daun rempah yang banyak digunakan dalam masakan Indonesia. Obat tradisional ini secara empiris berkhasiat dalam terapi hipertensi karena mengandung Saponin, flavonoid, dan tannin. Saponin yang terdapat dalam daun salam berfungsi sebagai antioksidan yang dapat mencegah terjadinya oksidasi sel pada tubuh. Jika pada tubuh semakin tinggi oksidasinya maka semakin tinggi peluang untuk terkena hipertensi. Jadi kandungan flavonoid yang terdapat pada daun salam dapat mencegah penyakit hipertensi dan menurunkan kolesterol pada darah. Senyawa saponin berfungsi untuk memicu tingginya kolesterol akibat adanya asam empedu sehingga dapat mengontrol kadar kolesterol dalam darah. Senyawa tannin berguna sebagai anti oksidan dan hipokolesterolemia. Senyawa tannin bereaksi dalam tubuh dengan cara bekerja sama dengan protein mukosa dan sel epitel pada usus sehingga dapat mengurangi penyerapan lemak. Kandungan senyawa yang dapat dalam daun salam tersebut dapat mempertahankan elastisitas pembuluh darah, sehingga dapat menurunkan kolesterol dalam darah. Terbukti dengan adanya penurunan tekanan darah dari 200 $\mathrm{mmHg}$ menjadi $130 \mathrm{mmHg}$ selama tujuh hari dengan variasi volume rebusan daun salam sebagai katalis alami (18).

Asumsi peneliti bahwanya penggunaan daun salam sebagi tanaman herbal sangat efektif untuk mengontrol tekanan darah yang dialami oleh individu yang mengalami hipertensi. Dan juga, daun salam sangat mudah untuk didapatkan sebagai herbal sehingga sangat mempermudah untuk dijadikan sebagai terapi non farmakologi pada pasein yang mengalami hipertensi.

Terapi relaksasi genggam jari yang dikombinasikan dengan terapi nafas dalam dapat mengurangi ketegangan fisik dan emosi karena genggaman jari pada tangan dapat menghangatkan titik titik keluar masuknya energi pada meridian yang terletak pada jari tangan apabila disertai dengan menarik nafas dalam dalam dapat mengurangi kerja saraf simpatis sehingga menyebabkan tekanan darah menurun. Titik titik meridian pada tangan akan memberikan rangsangan spontan rangsangan berupa gelombang listrik menuju otak. Gelombang tersebut diterima otak dan diproses dengan cepat menuju saraf pada organ yang mengalami gangguan, sehingga jalur energi menjadi lancar. Lancarnya jalur energi akan membuat otot otot dan tubuh menjadi rileks dan tenang, keadaan ini akan memyebabkan produksi hormon 
epinefrin dan noreprinefrin menurun. Penurunan produksi hormon tersebut dapat memberi efek kerja pada jantung dalam mekanisme kerja jantung pada saat melakukan pemompaan darah akan mengalami penururnan yang sehingga tekanan darah akan ikut mengalami penurunan (19).

Pada kondisi penurunan tekanan darah dan keadaan stress diperkiraka yaitu dipicu ole konsentrasi katekolamin plasma mempengaruhi aktivasi simptoadrenergik serta dapat menimbulkan terjadinya pelepasan stress released hormones. Pemberian musik dengan tempo yanga lambat dapat berpengaruh terhadap pelepasan katekolamin ke pembuluh darah, sehingga konsentrasi katekolamin yang ada pada plasma menjadi rendah. Sehingga mengakibatkan tubuh mengalami relaksasi, deyutan pada jantung mengalami penurunan dan tekanan darah menjadi terkontrol.

Healing touch merupakan terapi yang dipercaya mampu memperbaiki mekanisme ketidak seimbangan pada energy pasien dengan mengusap tangan di atas klien atau tubuh yang merasakan sakit (Kamalluddin, 2010).Otak dan kulit merupakan organ yang sangat urgen. Kulit yaitu system organ yang paling urgen, ia menempatkan nilai yang besar pada nilai terapeutik sentuhan terutama sebagai instrumen untuk mengontrol efek ketegangan. kulit adalah organ terluar yang dapat menerima stimulasi pada tubuh manusia, dan ketika reseptor sensoriknya distimulasi, hormon oksitoksin (yang menjadikan tubuh lebih baik dari sebelumnya) di saat yang bersamaan dilepaskan hormon kortisol (hormon stress) berkurang. Berhubungan dengan orang lain melalui sentuhan merupakan ekspresi simpatok secara lebih mudah serta pengalaman terapeutik yang kuat. Diberikan sentuhan sudah diterapkan secara global dalam konteks penyembuhan. Sentuhan digunakan untuk menjadikan rasa rileks, berkomunikasi dan juga mengaktivasi sifat tubuh terhadap penyembuhan pada diri (20).

Mekanisme penurunanan nilai tekanan darah pada latihan Slow Deep Breathing disebabkan karena meningkatnya aktivitas dari central inhibitory rythms yang memiliki dampak pada output simpatis. Penurunan pada output simpatis akan menyebabkan penurunan produksi hormone epineprin yang ditangkap oleh reseptor alfa sehingga akan mempengaruhi otot polos dari pembuluh darah sehingga terjadinya vasodilatasi, vasodilatasi pada pembuluh darah akan menurunkan tahanan perifer yang juga menyebabkan tekanan darah menjadi turun (21).

Slow Deep Breathing enam sampai sepuluh kali dalam satu menit yang dilakukan secara rutin akan merangsang pelepasan hormone endorpin yang akan membuat tubuh menjadi rileks selain itu juga akan merangsang sistem syaraf parasimpatis menjadi lebih aktiv dibanding sistem syaraf simpatis yang akan mempengaruhi kerja dari sistem baroreseptor dan mengakibatkan terjadinya vasodilatasi pada pembuluh darah dan menurunnya denyut jantung yang menyebabkan turunnya tekanan darah (22).

Pengaruh bekam terhadap tekanan darah tinggi disalah satunya bekam memiliki manfaat untuk merilekskan system saraf simpatik. Masalah pada system saraf simpatik ini memicu terjadinya sekresi enzim yang memiliki peran sebagai angiotensin renin. Sesudah system ini rileks dan kerjnya berkurang tekanan darah akan mengalami penunurun. Bekam berfungsi untuk menurunkan jumlah darah yang mengalirkan pembulu darah ke dalam darah sehingga dapat mengurangi tekanan darah. Bekam mengontrol kadar hormon aldosterone sehingga mengontrol tekanan pada darah. Bekam juga berperan memicu kerja reseptor - reseptor khusus yang terkait dengan penyempitan dan vasodilatasi pembulu darah (baroreseptor) sehingga pembulu darah mampu merespon stimulus dan meningkatkan kepekaannya pada kondisi yang penyebabkan terjadinya hipertensi (23).

Sesuai dengan ungkapan yang diberikan oleh responden yang ada pada penelitian ini mengatakan bahwa mereka mendapat rasa rileks sesudah melakukan terapi dengan menggunkan bekam. Responden juga mengungkapkan sakit kepala dan nyeri tengkuk yang dapat terjadi dengan frekuensi yang sering yang mereka alami mengalami penurunan bahkan hilang. Bekam memberikan mikrosirkulasi pembuluh darah sehingga menimbulkan efek pada relaksasi yang otot sehingga dapat mengendalikan tekanan darah. Individu yang mengalami kondisi dalam keadaan yang tertekan dapat memicu untuk hormon adrenalin dan kortisol dilepaskan ke dalam darah sehingga menyebabkan peningkatan tekanan darah.

Jika ini tidak dapat dicegah dan terjadi secara terus - menerus pada individu tersebut maka dapat menyebabkan terjadinya tekanan darah tinggi.. kondisi ini bahwa terapi dengan menggunkan teknik bekam bisa mengurangi adanya risiko terkena hipertensi dengan membantu memberikan efek rileks dan mikrosirkulasi pembuluh darah pada responden. Hasil penelitian ini menunjukkan bahwa terapi bekam memiliki pengaruh atau dampak yang baik terhadap tekanan darah. Kesimpulannya bahwa terapi bekam terbukti dapat memberikan pengaruh pada aktivitas kerja jantung, memperbaiki pembuluh darah dan memberikan rasa rileks dan pada akhirnya berpengaruh terhadap tekanan darah. Olehnya itu, terapi dengan menggunakan bekam efektif yang dapat membantu menurunkan tekanan darah atau mengontrol tekanan darah agar tetap stabil pada penderita hipertensi. 


\section{KESIMPULAN}

Berdasarkan hasil penelitian dari sepuluh jurnal bahwa penggunaan terapi non farmakologi pada pasien hipertensi dinilai efektif untuk menurunkan tekanan darah. Dari sepuluh terapi non farmakologi yang dianalisis oleh peneliti, terdapat lima terapi direkomendasikan untuk digunakan karena tekniknya sederhana, tidak membutuhkan alat dan bahan yang banyak, tidak memerlukan kemampuan khusus untuk menerapkannya dan dapat dilakukan oleh semua pasien yang mengalami hipertensi antara lain yaitu pemberian campuran tomat dan mentimun, pemberian pepaya mengkal dalam, pemberian rebusan daun salam, pemberian terapi relaksasi genggam jari dan nafas dalam dan terapi slow deep breathing.

\section{DAFTAR PUSTAKA}

1. Wolf K, Te Lindert M, Krause M, Alexander S, Te Riet J, Willis AL, et al. Physical limits of cell migration: control by ECM space and nuclear deformation and tuning by proteolysis and traction force. J Cell Biol. 2013;201(7):106984.

2. Cahyani HF. Hubungan shalat terhadap tekanan darah pada pasien hipertensi di Posbindu Anggrek Kelurahan Cempaka Putih Kecamatan Ciputat Timur. 2014;

3. Misbach J. Ancaman serius hipertensi di Indonesia. Simposia. 2007;34.

4. RI KK. Hasil utama riskesdas 2018. Jakarta Kemenkes RI. 2018;

5. Selatan DKS. Profil kesehatan Sulawesi Selatan 2015. Diperoleh dari http//dinkes-sulsel go $\mathrm{id} /$ new/images/pdf/profil/profil\%

20kesehatan\% 20sulsel. 2015;20(2008):20.

6. Sulistiawati AAAN, Prapti NKG, Lestari MPL. PENGARUH PEMBERIAN AIR REBUSAN DAUN ALPUKAT (Persea americana Mill.) TERHADAP TEKANAN DARAH PASIEN HIPERTENSI DI WILAYAH KERJA PUSKESMAS II DENPASAR SELATAN. COPING (Community Publ Nursing). 3(3).

7. Kemenkes RI. Riset Kesehatan Dasar Tahun 2013. Jakarta; 2013.

8. Warren-Findlow J, Seymour RB, Huber LRB. The association between self-efficacy and hypertension self-care activities among African American adults. J Community Health. 2012;37(1):15-24.

9. Joyce BM, Jane HH. Keperawatan Medikal Bedah Manajemen Klinis untuk Hasil yang Diharapkan, Edisi 8-Buku 2. Elsevier, Singapore; 2014.

10. Wulandari F. Hubungan tingkat pengetahuan perawat tentang perawatan paliatif dengan sikap terhadap penatalaksanaan pasien dalam perawatan paliatif di RS Dr. Moewardi surakarta. Universitas Muhammadiyah Surakarta; 2012.

11. BATUA P, TJEN VMVG. PENGARUH PEMBERIAN JAHE TERHADAP PERUBAHAN TEKANAN DARAH PADA PASIEN HIPERTENSI DI WILAYAH KERJA.

12. Yuliza E, Sabrian F, Hasanah O. Efektivitas Sari Buah Pepaya Mengkal (Carica Papaya) Terhadap Tekanan Darah Pada Pasien Hipertensi. 2016.

13. Lavenia C. Pemberian Juice Campuran Tomat dan Mentimun terhadap Penurunan Tekanan Darah kepada Penderita Hipertensi. J Ipteks Terap. 2017;9(1).

14. Panjaitan RGP, Bintang M. Peningkatan Kandungan Kalium Urin Setelah Pemberian Ekstrak Sari Buah Belimbing Manis (Averrhoa carambola)(THE INCREASE OF POTASSIUM URINE CONTENT AFTER ADMINSTRATION OF CARAMBOLA (AVERRHOA CARAMBOLA) FRUIT JUICE EXTRACT). J Vet. 2014;15(1):108-13.

15. Sukadana IM. Senyawa antibakteri golongan flavonoid dari buah belimbing manis (Averrhoa carambola Linn. L). J Kim (Journal Chem. 2009;

16. Kholish N. Bebas hipertensi seumur hidup dengan terapi herbal. Realbooks Yogyakarta. 2011;

17. Bogdanov S, Jurendic T, Sieber R, Gallmann P. Honey for nutrition and health: a review. J Am Coll Nutr. 2008;27(6):677-89.

18. Nurhayati EL. PENGARUH PEMBERIAN AIR REBUSAN DAUN SALAM (Syzigium polyanthum) TERHADAP PENURUNAN TEKANAN DARAH PADA PENDERITA HIPERTENSI DI LINGKUNGAN I KELURAHAN SEI AGUL TAHUN 2018. J Ilm PANNMED (Pharmacist, Anal Nurse, Nutr Midwivery, Environ Dent. 2018;13(2):19-22.

19. Sofiyah L, Ma'rifah AR, Susanti IH. PENGARUH TEKNIK RELAKSASI GENGGAM JARI TERHADAP PERUBAHANSKALA NYERI PADA PASIEN POST OPERASI SECTIO CAESAREADI RSUD PROF. DR. MARGONO SOEKARDJO PURWOKERTO. In: PROSIDING SEMINAR NASIONAL \& INTERNASIONAL. 2014.

20. Redho A, Sofiani Y, Warongan AW. Pengaruh Self Healing terhadap Penurunan Skala Nyeri Pasien Post Op. J Telenursing. 2019;1(1):20514.

21. Septiawan T, Permana I, Yuniarti FA. Pengaruh 
Latihan Slow Deep Breathing Terhadap Nilai Tekanan Darah Pada Pasien Hipertensi. J Ilmu Kesehat. 2018;6(2):111-8.

22. Hastuti RT, Insiyah I. Penurunan Tekanan Darah Dengan Menggunakan Tehnik Nafas Dalam (Deep Breathing) Pada Pasien Hipertensi Di Puskesmas Bendosari Kabupaten Sukoharjo. Interes J Ilmu Kesehat. 2015;4(2).

23. Irawan $\mathrm{H}$, Ari $\mathrm{S}$. Pengaruh terapi bekam terhadap penurunan tekanan darah pada klien hipertensi. J Ilmu Kesehat. 2017;1(1):18-24. 